\begin{tabular}{lc}
\hline \hline $\begin{array}{l}\text { MINING AND METALLURGY INSTITUTE BOR } \\
\text { UDK: 622 }\end{array}$ & $\begin{array}{l}\text { ISSN: 2334-8836 (Štampano izdanje) } \\
\text { ISSN: 2406-1395 (Online) }\end{array}$ \\
\hline \hline & DOI:10.5937/MMEB1502161S \\
LDiljana Savić ${ }^{*}$, Vladimir Radovanovic ${ }^{* *}$, Ljubinko Savic $^{*}$
\end{tabular}

\title{
BUSINESS SUCCESS MANAGEMENT
}

\begin{abstract}
This paper first discusses the essence and purpose of measuring the business success as well as the theoretical-methodological problems in defining model for measuring the overall business success. By expression and measurement of business success the efficiency and effectiveness the functioning of entire system of the company are quantitatively formalized and defined. Modern environment characterized by complexity, uncertainty, frequent and significant changes and the existence of strong competition requires companies to constantly improve the measurement systems for business success. In this paper, disputing the significance of financial performance measures for control and measurement of business success, the necessity to establish a new approach is highlighted where the financial indicators are combined with a large number of non-financial indicators. Experience in practical use of different models is a valuable knowledge showing managers in which direction to go in order to have more effective support in the management process.

Bearing this in mind, the mining companies should improve systems for control and measurement of business success, drawing on the experience of complex business practices or confirmation of all those measures which have acquired the attributes of an effective instrument of management.

Keywords: effectiveness, efficiency, measurement of business success, business success model, financial indicators, Prism performance.
\end{abstract}

\section{INTRODUCTION}

Expressing and measuring of business success is an integral element of the control system, of which adequacy, the effectiveness of the management process directly depends on.

The problem of measuring the overall business success is viewed in terms of purpose, essence and theoretical-methodological problems in defining the model for measuring the overall business success. This issue gains importance in contemporary environments which are characterized by complexity and uncertainty, and where the strong requirements are manifested for meeting the interests of different stakeholders. It is necessary that the mining enterprises take into account the interests of stakeholders in

making profit, paying the debts, reliable supply to consumers, adequate remuneration and care about the community.

In order to get knowledge on how to increase the effectiveness of the model for measuring business success, as a prerequisite for efficient management, the existing models are analyzed as a valuable contribution to economic theory and practice. This knowledge is useful for managers of mining companies.

\section{EFFECTIVENESS, EFFICIENCY AND BUSINESS SUCCESS}

As concepts that contain and link company objectives, resources and trans

\footnotetext{
*Faculty of Technical Science, K. Mitrovica,e-mail: ljsavic@open.telekom.rs

${ }^{* * *}$ Faculty of Technical Science, Čačak, e-mail: mrvladimirradovanovic@yahoo.com
} 
formation processes that form the basis for realization the objectives, efficiency and effectiveness are essential for every company. Recognizing many similar but different concepts for defining these essential and at the same time the key economic phenomena, it can be assumed that [1]:

- Effectiveness is the request to firstly make the selection of right goals and then, using available resources, to achieve the maximum realization of the selected goals.

- Efficiency is a requirement that the realization of a certain degree of selected targets is achieved with the least use of available resources, i.e. with the greatest rationality of their use.

Effectiveness is therefore focused on the choice of needs that will be met by the company, i.e. the selection of objectives and activities and efficiency is focused on the productive capacity and rational use of resources that a company has.

A similar interpretation is represented in the national literature by D. Grozdanović [2]. A differentiated concept of effectiveness and efficiency is based on the attempt of success differentiation in the work in relation to the market environment and in relation to the internal conditions in production. In doing so, however, the question of measuring or criteria is raised for design such determined success in the work. Effects in the domain of effectiveness depend on the effects in the area of production efficiency. And vice versa, the effects in the field of efficiency are dependent on effects on the basis of effectiveness.

Theoretical and methodological distinction between effectiveness and efficiency is not easy especially when it comes to their measurement. The product is the result of choice but also the result of more efficient or less efficient real production.

The effectiveness of the results is a measure of output tasks or achieving the goal. In the production organizational units that means to achieve planned production tasks qualitatively and quantitatively. Tasks can be achieved, but with the loss of sources used in the transformation process. Therefore both processes must be regarded. The efficiency of the results measure the costs of the sources used for the goal realization, that is the outputs in relation to inputs used [3].

Starting from the essence of economic efficiency and its apparent manifestations of the economy in general the effectiveness and efficiency as economic phenomena at the level of enterprise economy can be defined [1].

- Economic efficiency is essentially a manufacturing efficiency, i.e. the ability of efficient organization of the transformation of inputs into outputs of enterprises.

- Economic efficiency is an expression of the efficiency of the exchange because the selection of targets that meet societal needs and resources that define the production potential of the company ultimately comes down to the sale and purchase of inputs and outputs, i.e. the overall marketing activities.

- Allocative efficiency, term for efficiency in organization of production and exchange, is an expression of the overall efficiency of the company, which includes the effects of the efficiency and effects of effectiveness.

Integration of the efficiency and effectiveness in the unique expression of the overall economic efficiency is a function of measuring the performance of the overall company effects. Through understanding the overall effect, it is possible to manage effectively the economy of enterprises.

The quality of enterprise economy can be accessed through consideration the relationship between a uniquely understood product as the result of production and uniquely conceived social work introduced in reproduction in order to achieve that result.

Quantitative expression the quality of the economy is expressed by business success $\boldsymbol{P u}$, which is contained in the relations between the results of reproduction (output) and investments (inputs) to reproduction. 


$$
P_{u}=R\left(O_{u}\right) / U\left(I_{n}\right)
$$

The quality of enterprise economy as the expression of economic success in achieving objectives degree at the same time is the expression of effectiveness and efficiency of enterprise and business development. In accordance with the statement that the economic significance of efficiency and effectiveness, i.e. only economic efficiency, is just in the teconomy quality and it follows that business success is a quantitative expression of efficiency and effectiveness [2].

\section{MEASUREMENT OF BUSINESS SUCCESS}

The problem of measuring the total business success can be seen in terms of purpose, essence and theoretical methodological problems of defining the model for measuring business success.

The purpose of measuring the total business success of the company is clear information on the actual economic efficiency of enterprises, as well as on real economic effects of the new investments in the particular company of interest to the business owners. Continual measurement of business success is a realistic assumption for effective economic management of the company.

In the joint-stock companies, in which the ownership is separated from management, the measurement of business performance allows the owners to control managers who are engaged to manage the company.

The measurement of business success provides, in addition to the management efficiency, more realistic distribution of profits in the so-called financial groups of companies, more realistic view of actual effects of external growth.

The measurement of business success encourages the functioning of stock market, because potential investors (shareholders) have relevant information about their investments.
Expression of business success is a legal requirement without which the company cannot exist. The reported results serve as a basis for calculation and payment of dividends to the shareholders.

The owners, managers and state are interested in measuring the business success. Measuring the business success at the end of business period or continuously if required, is a necessary condition of efficient management and adequate satisfaction of stakeholders' interest.

Substantial interpretation suggests that the overall success of business of concrete enterprise is the expression of the overall economic efficiency. This means that it expresses its overall allocative ability as the ability for selection and procurement of inputs; efficient organization of production as a transformation process and selection and implementation of products and services as the output of enterprises. All economic effects that are manifested in the inputs and outputs to a specific company express the overall economic efficiency [1].

Business success becomes quantitatively determined when measured and estimated by corresponding economic methods formulated in certain indicators or models. The main economic criteria of efficiency are important starting point for expression, monitoring, controlling and directing the relationship between the results and investments. Production volume, total revenue, income and profit are measured on side of the results and workforce, total costs and capital employed on the side of investment.

$$
P_{u}=R\left(Q ; C ; D ; D_{b}\right) / U(L ; T ; S)
$$

If within the enterprise primary goal, the sub goals are viewed such as the production, accumulative and reproductive ability, the mentioned measures on the side of results and investments are formed in the tradition-

\footnotetext{
${ }^{1}$ Strategic constituents in the company are its stockholders or owners, customers, creditors, suppliers and other groups without whose cooperation enterprise cannot survive
} 
nally complex known indicators of productivity $(P=Q / L)$, economy $(E=C / T)$ and profitability of $R=D(D b) / S$. These partial indicators are determined by the elements of results and investments; they are conditioned by factors forming quality of economy and activities to achieve the efficiency in the use of resources [4].

Expressing the business success by partial indicators as the enterprise economy measures shows the efficiency in functionning the production-financial company's subsystems. This allows the control and guidance the quality of certain subsystems of the economy to a unique integrated goal to achieve the efficiency of the whole company system. However, in expressing and managing the dynamics of business success, divergence and disadvantages of partial indicators as well as the complexity of this issue are manifested. It is caused by different intensity and direction of movement the elements of results and investments under the influence of positive or negative effects within operating activities.

The contemporary theory and practice resolve the expression and measurement problem of business success accepting two attitudes [2]:

- the first is based on the use of a number of individual indicators, where the denominator term is given most often in the form of quantitative evaluation, which is generally not objectified on some basis

- the second is based on an attempt to, along with numerous difficulties and constraints faced by the modern theory and practice, formulate and uses the synthetic term of business success, in the form of more or less integrated, maximum possible objectified model, which, along with mandatory additionnal qualitative indicators, physical expresses the change of overall economic quality.

The scope and content of any set of indicators or integral model of business success, should, on the basis of the basic criteria of economic efficiency, primarily meet the informational, management-control and motivational functions in business [5].

\section{THEORETICAL AND \\ METHODOLOGICAL PROBLEMS OF DEFINING A MODEL FOR MEASURING THE BUSINESS SUCCESS}

Moving from a large number of partial indicators on a single indicator of overall efficiency requires solving the problem of reduction to a common denominator for the inputs and outputs of enterprises, as well as developing a complex business and information systems in the company, developed from a concrete model for measuring the business success.

In the constitution of model for expressing the overall business success, a model Econometer deserves a special attention as the original creation made by S. Kukoleča [6] which in dynamics record and report all connections and all changes in the shape of results and investments, reduced to a single common measure - working equivalent. The high level of abstraction and perfection in design and development of business success models in general, and specifically to the factors of conditionality, imposed the impression that it is difficult or impossible to achieve its implementation. This is especially true for a period of sixties when there were no support information systems in our companies. Also, that information base, required for measurements according to this model, on a small scale is associated with the official accounting and financial system. This represented one of the main obstacles for the use in practice.

Diligent efforts are also done by domestic scholars (D. Grozdanović and N. Malenović) on constituting the model for overall performance measurement of business success which overcomes some limitations of the original model and its subsequent modification (also by the two above mentioned authors), especially regarding the use of financial reporting information as a basis for calculation of certain elements [7]. 
The existing theoretical and practical instruments for controlling and directing business development and growth of the company do not allow consideration of a realistic picture of actual efficiency of modern enterprises. Many theoretical models derived from different company theories could not be applied to solve the specific problems in practice of companies. Thus, mathematical methods and models have limited utility in the application and were used for solving hypothetical cases rather than specific problems in the economy of companies.

The problem of efficient business of enterprises in management theories is formulated as the problem of determining maximum usefulness of managers, but since managers do not have unlimited discretion and their goals can be achieved with the conditions set by the owners of shareholders, maximizing of the utility function occurs as the result of problem solutions caused by maximization. Except a dichotomy of interests of the owners on one side, and managers, on the other side, does not identify the other important interests. Access to the objectives of the company changed over the time and techniques and methods of achieving the goals improved, but the basic objectives and their economic content were marginalized.

Financial indicators as the basis of traditional systems for measurement and control of business success have a clear control role bounded by certain period. There from derived sets of various indicators, indices and ratio numbers, just show what the result of business in companies is during the past period and it is not expressed through the overall business success, but according to the partial statements of certain conditions and effects.

With the development of theories that deal with the economy of enterprises, the preconditions are created for development of models to measure the business success for such control of company and management of its economy to emphasize the positive and to reduce negative consequences with satis faction of all $\mathrm{t}$ essential interests which are manifested in connection with business, growth and development.

\section{FINANCIAL INDICATORS AS THE BASIS OF TRADITIONAL SYSTEMS OF MEASUREMENT AND CON- TROL THE BUSINESS SUCCESS}

Common to all traditional systems of financial control and measurement the business success is that they are all based on data that can be obtained on the basis of the accounting system. Giving priority to the use of quantitative accounting information is explained by the fact that accounting as a single integrated system for quantitative analysis of the company, characterized by integrity of business and financial activities of the company and the advantage of numerical expressions from which a value objectivism is derived. Also, the advantage of accounting information is manifested in their capacity to turn different conditions, trends and relationships into a universal, generally accepted unique numeric expression.

An integrated set of financial statements of most companies in the international practice is consisted of a balance sheet $^{2}$ (the statement of financial position), income statement (profit and loss). Although being more and more favored, cash flow statement is not accepted in all countries $^{3}$. Regardless of establishment on the

2 One of the key changes in the revised IASI, published in 2007 refers to the replacement of balance sheet with statement of financial position of the company. As a reason for this terminological changes are functions of this basic financial statement.

3 According to accepted accounting standards, in addition to balance sheet, small businesses companies in our country are obliged to submit income statement and statistical annex to the Business Registers Agency (APR), a mediumsized and large companies are obliged to submit cash flow statement and statement of changes in capital. 
same business and financial transactions and financial universal quantification of these transactions, the financial statements set as an objective chronicler of company gives a variety of information on its activities for a certain period.

Basic information content of the balance sheet date is a book value of the company or the state of assets, liabilities and equity (net asset value) on a particular day.

Income statement is known as a profit and loss account. Basic information content of the income statement is profitability. Balance sheet presents the information on income, expenditure and net profit / loss for the certain period.

All revenues and expenses of a conventionally adopted accounting period, mutual confronted and presented in accordance with the relevant principles and in the appropriate reporting forms, allow determination of the results, profit as positive and loss as negative differences, which at the end of the accounting period are included in the balance sheet as an increase or decrease (the own) capital. This understanding of the income statement indicates the existence of a systematic and organic links between balance sheet and income statement, and this fact indicates that these financial statements in terms of evaluation the efficiency of operations are treated as complementary and interdependent accounting products [8].

Cash-flow statement shows turnover on cash account through cash inflows and outflows as well as free cash flow generated in the period. Cash Flow Statement shows the business, financial and investment inflows and outflows of cash flows of the company during the reporting period. Basic information for control in cash flow statement is liquidity. Also, the cash flow statement carries information about the possibilities of creating value if a discounted free cash flow is implemented.

Certain financial statement items, shown in absolute values, do not give enough information for management. Ratio numbers are obtained by bringing particular positions from balance sheet, income statement and other statements in appropriate relations.

In the control process, the ratio numbers are compared to the past results or the competition results, that is, ratio numbers can be used to monitor the results of the company over time or to monitor the relative position of the company in relation to the competitors. In any case, these relative values provide much richer information than absolute values analyze (financial statement). All ratio numbers can be classified into four major groups: liquidity indicators, turnover (activities) indicators, indicators of solvency (financial structure) and indicators of profitability (profitability) [9].

The aforementioned indicators are actually operational performance measures, namely indicators of the success that measure results of operational decisions. It is obvious that the effects of operational decisions include effects of strategic and tactical decisions [10].

In addition to the simple ratio numbers there are complex ratio numbers that arise by combining the ratio numbers, following a substantial part business process or specific aspects of the business. DuPont formula leads to a synthetic expression of profitability which allows establishing the change as well as causes of changes in profitability, because the overall profitability, that is, the return on total assets is seen as a result of interactions, or interactions of partial indicators of profitability [11].

For the purposes of managers as the internal users of financial and accounting reports in the company, the additional reports on operations can be made which should contribute to making the rational management decisions and taking appropriate actions.

The importance of the financial statements, which reflect the financial business activities of the company as a whole, is reflected in the fact that the analytical interpretation of data contained therein enables identification and monitoring the key 
financial performance measures of enterprise efficiency. In addition to the traditional criteria of MIA, indicators are used lately that have their stronghold in the concept of value-based management. One of the most important is the economic value added (EVA). The following indicators are lately often used by economic analysts: Earning Before Interest (EBIT) and Earning Before Interest, Taxes, Depreciation and Amortization (EBITDA)

\section{RESULTS OF ECONOMIC THEORY AND PRACTICE IN DEFINING THE MODEL FOR MEASURING THE OVERALL BUSINESS SUCCESS}

Despite irreplaceable role of the financial criteria, it is necessary to emphasize its imperfections and incompleteness for the purposes of valid analysis and evaluation of effectiveness. The use of traditional financial measures has certain drawbacks and limitations that are primarily related to: presentation of events that occurred in the previous period, unreliability of comparison base for a longer period, not giving enough importance to the business environment by ignoring the perspective of consumers and competitors. A problem of traditional measures, based on financial indicators, is that they do not take into account the intangible value contained in the knowledge that can greatly increase market value of the company.

Changes in the environment, globalization of the world economy, strong competition and development of information technology leads to the changes in the traditional control apparatus. Industrial economy characterized by physically tangible assets is replaced by a new economy where the most valuable resource becomes intangible assets that include relationships with consumers, employee skills and their knowledge, information and organizationnal culture favorable for innovation, problem solving and general improvement of organization [12].

In terms of developed market, the only sustainable way to create value for business owners at the same time is value creation for their stakeholders. Stakeholders therefore have legitimate interests in the company performance, as well as the specific requirements and needs that arise from the relationship in carrying out certain activities. In addition, the primary (active) stakeholders have a formal, official and contractual relationship with the company, while all the others can be considered as the secondary. Orientation to stakeholders implies that the model of business success include indicators of success in achieving the individual goals of all stakeholders as well as measurements of achieving these goals both expressed by appropriate indicators.

One of the most important roles of management is to find a balance between acceptable financial responsibilities towards the owners and strategic responsibilities to the other stakeholders. The higher the quality of the relationship of companies with stakeholders such as customers, employees, suppliers, communities and others, leads to better financial performance, and ultimately to a higher enterprise value, and shareholding wealth [13].

Model Prism performances - Based on said, and taking into account the causal processes among stakeholders, one of the modern model is formulated, so-called Performance Prism (A. Neely) which is considered to be an integral model because it combines the elements oriented on stakeholders and elements of process oriented models [5]. Prism performance model is shown in Figure 1 . 


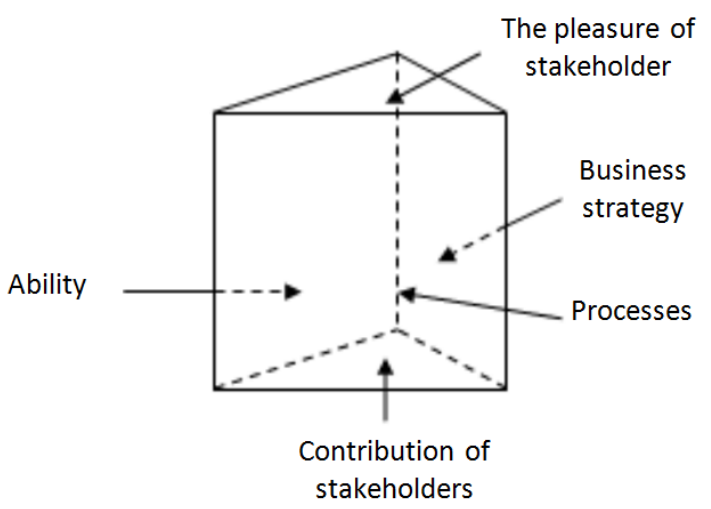

Figure 1 Prism performance as a model showing business success, according to [14]

Model Prism performance provides five different but related views, and thus reflects the business success of the company stated by set of indicators differentiated into five key groups, as well as answers to the questions [14]:

- The pleasure of stakeholder (top of the prism) - who are the key stakeholders and what they want or what they need;

- Business strategy (side of the prisms) which strategy company needs to implement to satisfy the mentioned desires or needs

- Processes (side of the prisms) - what critical processes a company should apply to the set objective, favoring socalled processes that add value to the investment in reproduction

- Ability (side of the prisms) - what ability the key stakeholders should have (employees, customers, community and the owners of capital) in the exercise of applied processes and finally

- Contribution of stakeholders (bottom of the prisms) - what contribution the company can expect from stakeholders if the company's management supports and develops the skills of stakeholders

Management on the basis of these criteria involves defining the target perfor mance measures, comparing achievements with target-setting values, identifying deviations and causes (factors) of deviations, and finally identifying corrective management action. The model is considered valuable because it highlights the dimension of measures ability (resources). The main disadvantage is a big number of criteria that, considering the limited time and ability attention of managers, cannot be used operationally.

Numerous references prove that the application of multidimensional performance measurement system contributes to the effectiveness thereof (Domanović, 2013, according to: Malina, M. A., \& Selto, F. H. 2001; Ittner, C. D and others 2003; Davis, S., \& Albright, T. 2004; Crabtree, A. D \& De Busk, G.K 2008; Van der Stede, W.A. and others 2006; Tung, A. and others 2011). Most of these studies examined the effectiveness of these systems from the perspective of contribution the same financial results [15].

The analyzed models of measurements as well as the other existing models that have proven their applicability in practice are of particular importance to improve the management process. Combining the existing models creates the new ones. The 
improved measurement systems provide the real preconditions for efficient management, with appropriate support of information systems.

\section{CONCLUSION}

In economic theory and business practice in companies, the issues of measuring overall business success is very live and still insufficiently rounded. From the management aspect the design of quality aggregate criteria requires previously solving extremely complex problem of reducing to a common denominator of different criteria for inputs and outputs of enterprises as well as development and use of appropriate information system for monitoring the budget and so the designed aggregate size of business success. Economic theory has offered a solution in the form of the optimal model Econometer. Model of total performance of business success tries to overcome some limitations of the original model and its subsequent modifications, especially regarding the use of financial reporting information as the basis for calculation the certain elements.

The financial measures have an irreplaceable role in the evaluation of enterprise business success; however, it is necessary to point to their imperfection and incompleteness with the need for a valid analysis of business success. In the modern period there is inability of financial indicators to include the intangible resources of the company (intellectual capital) and level of achievement of non-financial company goals (relationship with customers, employees) who are critical for business success in the modern period.

Effective measurement system is one that includes a set of financial and nonfinancial measures that will enable managers to successfully deal with a large number of business activities and focus on the key factors of business success. Model Prism performance is one such proposal (attempts). But there is no stopping here.
In the aim of real overview of the effectiveness and efficiency of the company, looking for solutions providing a new paradigm of enterprise and its appropriate model will continue.

The considered problem in this paper is useful for management of mining companies which will, through greater responsibility to their stakeholders, acquire the attributes of successful enterprise.

\section{REFERENCES}

[1] M. Nikolić, N. Malenović, D. Pokrajčić, B. Paunović, Enterprise Economics, Faculty of Economics, Kragujevac, 2003, pp. 122,136,475;

[2] D. Grozdanović, Fundamentals of Enterprise Economics, Faculty of Economics, Kragujevac, 2003, pp. 23, 25,456:

[3] M. Milisavljević, Contemporary Strategic Management, Megatrend University of Applied Sciences, Belgrade, 2005, p. 5;

[4] Lj. Savić, The Tole of Management in Improving the Effectiveness and Efficiency of the Company, Doctoral Dissertation at Megatrend University, Faculty of Business Studies, Belgrade, 2010, p.100;

[5] M. Ratković Abramović, Management of Dynamics of Business Success, the Copyright Issue, ŽELNID - Belgrade, 2005, pp. 67,79;

[6] S. Kukoleča, Ekonometar, Consulting Center, Belgrade, 1994;

[7] B. Krstić, Model of Measurement the Performance of the Overall Business Success of the Company, Faculty of Economics, Niš, 2007;

[8] V. Domanović, J. Bogićević, The Possibilities of the Balanced Scorecard Concept Implementation in Serbia, NDE, Palić, 2011;

[9] B.Pešalj, Company Performance Measurement, Faculty of Economics, Belgrade, 2006, p.63; 
[10] D. Djuričin, S. Janošević, Dj. Kaličanin, Management and Strategy, Faculty of Economics, Belgrade, 2013, p. 161;

[11] D. Pokrajčić, Enterprise Economics, Copyright Issue, Čigoja štampa, Belgrade, 2002, p.356;

[12] R. Kaplan and D. Norton, Having Trouble With Your Strategy? Then Mapit!, Harvard Business Review, September-October, 2000, p. 4;
[13] Dj. Kaličanin, The Formulation and Implementation of Strategies of Value Creation, Doctoral Dissertation, Faculty of Economics, Belgrade, 2005, p.15;

[14] A. Neely, Business Performance Measurement, Cambridge University Press, 2003, p. 153;

[15] V. Domanović, The Effectiveness of the Performance Measurement in Terms of Contemporary Business Environment, Ekonomski horizonti, Faculty of Economics, Kragujevac, April 2013. 


\begin{tabular}{ll}
\hline \hline INSTITUT ZA RUDARSTVO I METALURGIJU BOR & ISSN: 2334-8836 (Štampano izdanje) \\
UDK: 622 & ISSN: 2406-1395 (Online) \\
\hline \hline
\end{tabular}

UDK: $330.1: 061.5(045)=163.41$

DOI:10.5937/MMEB1502161S

\author{
Ljiljana Savić, Vladimir Radovanovic ***, Ljubinko Savic **
}

\title{
UPRAVLJANJE POSLOVNIM USPEHOM
}

\section{Izvod}

U ovom radu se prvo ukazuje na suštinu i svrhu merenja poslovnog uspeha kao i na teorijskometodološke probleme u definisanju modela za merenje ukupnog poslovnog uspeha. Izražavanjem $i$ merenjem ukupnog poslovnog uspeha kvantitativno se formalizuje $i$ definiše efikasnost $i$ efektivnost funkcionisanja celokupnog sistema preduzeća. Savremeno okruženje koje odlukuje složenost, neizvesnost, česte i značajne promene i postojanje izražene konkurencije zahteva od preduzeća da stalno unapređuju sisteme merenja poslovnog uspeha. U radu se, ne sporeći značaj finansijskih merila za konntrolu i merenje poslovnog uspeha, ističe neophodnost uspostavljanja novih pristupa gde su finansijski pokazatelji kombinovani sa velikim brojem nefinansijskih pokazatelja. Iskustva u praktičnoj primeni pojedinih modela su vredna saznanja u kom pravcu treba dalje ići da bi menadžeri imali efikasniju podršku u upravljačkom procesu.

Imajući ovo u vidu rudarska preduzeća treba da unapređuju sisteme za kontrolu i merenje poslovnog uspeha, crpeći iskustva iz kompleksne poslovne prakse odnosno utvrđivanju svih onih merila koja su stekla atribute efikasnog upravljačkog instrumenta.

Ključne reči: efektivnost, efikasnost, merenje poslovnog uspeha, model poslovnog uspeha, finansijski pokazatelji, prizma performansi

\section{UVOD}

Izražavanje i merenje ukupnog poslovnog uspeha sastavni je element upravljačkog sistema, od čije adekvatnosti neposredno zavisi i efikasnost samog upravljačkog procesa.

Problematika merenja ukupnog poslovnog uspeha sagledava se sa aspekta svrhe, suštine $\mathrm{i}$ teorijsko-metodoloških problema u definisanju modela za merenje ukupnog poslovnog uspeha. Ova problematika dobija na značaju u uslovima savremenog okruženja koje karakteriše složenost i neizvesnost i gde se ispoljavaju snažni zahtevi za zadovoljavanjem interesa različitih stejkholdera. Rudarska preduzeća takođe moraju uvažavati interese neposrednih stejkholdera u sticanju profita, isplati dugova, pouzda-

nom snabdevanju kupaca, adekvatnom nagrađivanju, vođenjem računa o doslednosti i dr.

U cilju sticanja saznanja o tome kako povećati efektivnost modela za merenje poslovnog uspeha danas, kao pretpostavke za efikasnije upravljanje analiziraju se postojeći modeli kao vredni doprinosi ekonomske teorije i prakse. Ova su znanja korisna za menadžersku strukturu rudarskih preduzeća.

\section{EFEKTIVNOST, EFIKASNOST I POSLOVNI USPEH}

Kao koncepti koji u sebi sadrže i povezuju ciljeve preduzeća, resurse i transfor-

\footnotetext{
* Fakultet tehničkih nauka u Kosovskoj Mitrovici,e-mail: ljsavic@open.telekom.rs

***Fakultet tehničkih nauka u Čačku, e-mail: mrvladimirradovanovic@yahoo.com
} 
macione procese koji predstavljaju osnovu za realizaciju ciljeva, efikasnost i efektivnost su od suštinskog značaja za svako preduzeće. Uvažavajući brojne slične, pa i različite koncepte za definisanje ovih suštinskih i istovremeno ključnih ekonomskih fenomena može se poći od toga da [1]:

- Efektivnost podrazumeva zahtev da se prvo izvrši izbor pravih ciljeva a potom korišćenjem raspoloživih resursa ostvari maksimalna realizacija izabranih ciljeva.

- Efikasnost predstavlja zahtev da se realizacija određenog stepena izabranih ciljeva ostvari uz najmanje korišćenje raspoloživih resursa, odnosno uz najveću racionalnost njihove upotrebe.

Efektivnost je prema tome orijentisana na izbor potreba koje će preduzeće zadovoljavati, odnosno izbor ciljeva i delatnosti kojima če to obezbediti, a efikasnost na proizvodnu sposobnost i racionalnost upotrebe resursa kojima preduzeće raspolaže.

Slično tumačenje zastupa u domaćoj literaturi D. Grozdanović [2]. Diferencirani koncept efektivnosti i efikasnosti bazira na pokušaju diferenciranja uspeha $\mathrm{u}$ radu $\mathrm{u}$ odnosu na tržišno okruženje i u odnosu na interne uslove u proizvodnji. Pri tome se, međutim, otvara pitanje merenja odnosno kriterijuma za projektovanje tako određene uspešnosti u radu. Efekti u domenu efektivnosti zavise od efekata u domenu proizvodne efikasnosti. Važi i obratno, efekti u domenu efikasnosti su uslovljeni efektima po osnovu efektivnosti.

Teorijsko-metodološko razgraničenje efektivnosti i efikasnosti nije nimalo jednostavno, a pogotovo kada se radi o njihovom merenju. Proizvod je rezultat izbora ali i rezultat efikasnije ili manje efikasne ostvarene proizvodnje.

Efektivnost rezultata je merilo zadataka outputa ili ostvarenja cilja. U proizvodnim organizacionim jedinicama to znači ostvariti planirane proizvodne zadatke kvalitativno i kvantitativno. Zadaci se mogu ostvariti, ali uz gubitak izvora korišćenih u transforma- cionom procesu. Zbog toga se moraju posmatrati oba procesa. Efikasnost rezultata meri troškove korišćenih izvora za ostvarenje cilja, tj. outputa u odnosu na korišćene inpute [3].

Polazeći od suštine ekonomske efikasnosti i njenih pojavnih manifestacija $u$ ekonomiji uopšte efektivnost i efikasnost kao ekonomski fenomeni na nivou ekonomije preduzeća mogu se definisati [1]:

- Ekonomska efikasnost u suštini predstavlja proizvodnu efikasnost odnosno sposobnost efikasnog organizovanja transformacije inputa $u$ outpute preduzeća.

- Ekonomska efektivnost predstavlja izraz efikasnosti razmene jer se izbor ciljeva kojima se definišu proizvodni potencijali preduzeća u krajnjoj liniji svodi na prodaju outputa i nabavku inputa, odnosno na sveukupne marketing aktivnosti.

- Alokativna efikasnost kao izraz efikasnosti organizovanja proizvodnje i razmene predstvlja izraz ukupne efikasnosti preduzeća koja u sebe uključuje i efekte efikasnosti i efekte efektivnosti.

Integracija efikasnosti i efektivnosti u jedinstveni izraz ukupne ekonomske efikasnosti je u funkciji merenja ukupnih efekata uspešnosti preduzeća. Kroz sagledavanje ukupnog efekta se omogućava efikasnije upravljanje ekonomijom preduzeća. Kvalitet ekonomije preduzeća, može da se oceni kroz sagledavanje odnosa izemeđu jedinstveno shvaćenog proizvoda, kao rezultata proizvodnje i jedinstveno shvaćenog društvenog rada unesenog u reprodukciju u cilju ostvarivanja tog rezultata.

Kvantitativni izraz kvaliteta ekonomije izražen je poslovnim uspehom $\boldsymbol{P}_{\boldsymbol{u}}$, koji je sadržan u odnosima između rezultata reprodukcije (outputa) i ulaganja (inputa) u reprodukciju

$$
P_{u}=R\left(O_{u}\right) / U\left(I_{n}\right)
$$

Kvalitet ekonomije preduzeća, kao izraz stepena ekonomske uspešnosti u ostvariva- 
nju ciljeva, istovremeno je i izraz uspešnosti u efektivnosti i efikasnosti preduzeća u poslovanju i razvoju. Saglasno sa konstatacijom da je ekonomsko značenje efektivnosti i efikasnosti, odnosno samo ekonomske efikasnosti upravo u kvalitetu ekonomije sledi istovremeno zaključak da je i poslovni uspeh kvantitativni izraz efikasnosti i efektivnosti [2].

\section{MERENJE UKUPNOG POSLOVNOG USPEHA}

Problematika merenja ukupnog poslovnog uspeha može se sagledati sa aspekta svrhe, suštine i teorijsko-metodoloških problema definisanja modela za merenje poslovnog uspeha.

Svrha merenja ukupnog poslovnog uspeha preduzeća su jasne informacije o stvarnoj ekonomskoj efikasnosti preduzeća kao i o realnim ekonomskim efektima novih investicija u konkretno preduzeće za koje su zainteresovani vlasnici preduzeća. Kontinuelno merenje poslovnog uspeha je realna pretpostavka za efikasnije upravljanje ekonomijom preduzeća.

U akcionarskim preduzećima u kojima je vlasništvo odvojeno od upravljanja merenje poslovnog uspeha omogućuje vlasnicima kontrolu menadžera koje su angažovali da upravljaju preduzećem.

Merenje ukupnog poslovnog uspeha obezbeđuje pored efikasnosti upravljanja i realniju raspodelu profita tzv. finansijskim grupacijama preduzeća, realnije sagledavanje stvarnih efekata eksternog rasta.

Merenje ukupnog poslovnog uspeha podstiče funkcionisanje berze, jer potencijalni investitori (akcionari) imaju relevantne informacije za svoje investicije.

Izražavanje poslovnog uspeha je i zakonski uslov bez koga preduzeće ne može da postoji. Iskazani rezultati poslužiće kao osnova za obračun i isplatu dividendi akcionarima.

Za merenje poslovnog uspeha, zainteresovani su vlasnici, država i menadžeri. Merenje poslovnog uspeha na kraju poslovnog perioda ili kontinuelno po potrebi je neophodan uslov efikasnijeg menadžmenta, kao i adekvatnije zadovoljavanje interesa različitih stejkholdera. ${ }^{1}$

Suštinsko tumačenje ukazuje na to da je ukupni poslovni uspeh konkretnog preduzeća izraz ukupne ekonomske efikasnosti. To znači da izražava njegovu ukupnu alokativnu sposobnost kako kroz sposobnosti: za izbor i nabavku inputa, efikasno organizovanje proizvodnje kao transformacionog procesa tako i izbor i realizaciju proizvoda i usluga kao outputa preduzeća. Svi ekonomski efekti koji se pojavno manifestuju na inputima i na outputima konkretnog preduzeća izražavaju njegovu ukupnu ekonomsku efikasnost [1].

Poslovni uspeh postaje kvantitativno određen kada je izmeren i ocenjen odgovarajućim ekonomskim metodama uobličenim $\mathrm{u}$ određene indikatore ili modele. Osnovni ekonomski kriterijum efikasnosti je značajno polazište izražavanja, praćenja, kontrole i usmeravanja odnosa između pojavnih oblika rezultata i ulaganja. Na strani rezultata mere se: obim proizvodnje, ukupan prihod, dohodak i dobitak, a utrošena radna snaga, ukupni troškovi i angažovani kapital na strani ulaganja.

$$
P_{u}=R\left(Q ; C ; D ; D_{b}\right) / U(L ; T ; S)
$$

Ako se u okviru osnovnog cilja preduzeća posmatraju podciljevi kao: proizvodna, akumulativna i reproduktivna sposobnost navedena merila na strani rezultata i na strani ulaganja uobličavaju se $\mathrm{u}$ tradicionalno poznate indikatore kompleksa produktivnosti $(P=Q / L)$, ekonomičnosti $(E=C / T)$ i rentabilnosti $\left(R=D\left(D_{b}\right) / S\right)$ [4].

Izražavajući poslovni uspeh parcijalnim indikatorima kao merilima stanja ekonomije preduzeća iskazuje se efikasnost funkcionisanja proizvodno-finansijskog podsistema

\footnotetext{
${ }^{1}$ Strategijski konstituenti preduzeća su njegovi stejkholderi, odnosno vlasnici, kupci, kreditori, dobavljači i ostale grupe bez čije saradnje ne može da opstane.
} 
preduzeća. Na taj način omogućuje se kontrola i usmeravanje kvaliteta pojedinih podsistema ekonomije ka jedinstvenom integralnom cilju ostvarivanja efikasnosti celog sistema preduzeća. Međutim pri iskazivanju i upravljanju dinamikom ukupnog poslovnog uspeha ispoljavaju se divergentnost $\mathrm{i}$ nedostaci parcijalnih indikatora $\mathrm{i}$ kompleksnost ove problematike. To je uslovljeno različitim intenzitetom i smerom kretanja samih elemanata rezultata i ulaganja pod uticajem pozitivnih ili negativnih dejstava u sklopu poslovnih aktivnosti.

Problem svodnog izražavanja i merenja ukupnog poslovnog uspeha savremena teorija i praksa rešava prihvatanjem dva stava [2]:

- prvi se bazira na korišćenju brojnih pojedinačnih indikatora, pri čemu je svodni izraz dat najčešće u vidu kvalitativne ocene, koja po pravilu nije objektivizirana po nekom osnovu,

- drugi zasnovan na pokušaju da se, uz brojne teškoće i ograničenja na koje nailazi savremena teorija i praksa, formuliše i koristi sintetički izraz poslovnog uspeha, u vidu, manje ili više integralnog, maksimalno moguće objektiviziranog modela koji, uz obavezne dopunske kvalitativne pokazatelje, agregatno iskazuje promenu ukupnog ekonomskog kvaliteta preduzeća.

Obuhvat i sadržaj, bilo seta indikatora, bilo integralnog modela ukupnog poslovnog uspeha, treba da, na osnovu bazičnog kriterijuma ekonomske efikasnosti, prvenstveno zadovolji informacionu, upravljačko-kontrolnu i motivacionu funkciju u poslovanju preduzeća [5].

\section{TEORIJSKO-METODOLOŠKI} PROBLEMI DEFINISANJA MODELA ZA MERENJE POSLOVNOG USPEHA

Prelazak sa velikog broja parcijalnih pokazatelja na jedan jedinstven pokazatelj ukupne efikasnosti zahteva rešavanje problema svođenja na zajednički imenitelj za inpute i outpute preduzeća, kao i razvijanje kompleksnog poslovno-informacionog sistema $\mathrm{u}$ preduzeću razvijenog iz konkretnog modela za merenje poslovnog uspeha.

U konstituisanju modela za izražavanje ukupnog poslovnog uspeha posebnu pažnju zavređuje model Ekonometar kao originalna tvorevina S. Kukoleče [6], kojim se u dinamici evidentiraju i iskazuju sve veze $i$ sve promene oblika rezultata i ulaganja, svedenih na jedinstvenu zajedničku meru radni ekvivalent. Visok nivo apstrakcije i perfektnosti u koncipiranju i razradi modela poslovnog uspeha u globalu, te posebno prema faktorima uslovljenosti, nametnuli su utisak da je teško ili nemoguće ostvariti njegovu primenu. To važi naročito za peiod šesdesetih godina kada nije postojala podrška informacionih sistema u našim preduzećima. Takođe ta informaciona osnova, potrebna za merenje prema ovom modelu u maloj meri je povezana sa zvaničnim računovodstveno-finansijskim sistemom. Ovo je predstavljalo jednu od bitnih prepreka za značajniju primenu u praksi.

Vredni su napori takođe domaćih teoretičara (D. Grozdanović i N. Malenović) na konstituisanju modela Merenje ukupne performanse poslovne uspešnosti kojim se prevazilaze određena ograničenja izvornog modela i njegovih kasnijih modifikacija (takođe od strane pomenutih autora) posebno u pogledu korišćenja sistema finansijskog izveštavanja kao informacione osnove za proračun pojedinih elemenata [7].

Postojeći teorijski i praktični instrumenti kontrole i usmeravanja poslovanja, rasta razvoja preduzeća ne omogućavaju sagledavanje realne slike stvarne efikasnosti savremenih preduzeća. Mnogi teorijski modeli, proizašli iz različitih teorija preduzeća, nisu mogli biti primenjeni za rešavanje konkretnih problema u praksi preduzeća. Tako su matematički metodi i modeli imali ograničene domete u primeni, služili su za rešavanje hipotetičkih slučajeva, a ne konkretnih problema u ekonomiji preduzeća. 
Problem efikasnog poslovanja preduzeća se u menadžerskim teorijama formuliše kao problem određivanja maksimalne korisnosti menadžera, ali s obzirom da menadžeri ne poseduju neograničenu diskreciju i da svoje ciljeve mogu da ostvare uz uslove koje postavljaju vlasnici - akcionari, maksimiziranje funkcije korisnosti se javlja kao rezultat rešenja problema uslovljene maksimizacije. Sem dihotomije interesa vlasnika $s$ jedne i menadžera $s$ druge strane ne identifikuju se drugi značajni interesi. Pristup ciljevima preduzeća se tokom vremena menjao gde su usavršavane tehnike i metode ostvarivanja ciljeva ali su bazični ciljevi i njihova ekonomska sadržina marginalizovani.

Finansijski pokazatelji kao osnova tradicionalnih sistema merenja i kontrole poslovnog uspeha imaju svoje jasne kontrolne uloge omeđene određenim vremenskim periodima. Iz njih izvedeni setovi raznih indikatora, indeksa i racio brojeva, samo pokazuju kakav je rezultat poslovanja preduzeća $\mathrm{u}$ proteklom periodu i to ne izraženo kroz ukupan poslovni uspeh već prema parcijalnim iskazima pojedinih stanja i efekata.

Razvojem teorija koje se bave ekonomijom preduzeća stvaraju se pretpostavke za usavršavanje modela za merenje poslovnog uspeha, za takvu kontrolu preduzeća i upravljanje njegovom ekonomijom da se pozitivne konsekvence potenciraju, a negativne smanje na najmanju meru uz zadovoljenje svih bitnih interesa koji se ispoljavaju $\mathrm{u}$ vezi sa njegovim poslovanjem, rastom i razvojem.

\section{FINANSIJSKI POKAZATELJI KAO OSNOVA TRADICIONALNIH SISTEMA MERENJA I KONTROLE POSLOVNOG USPEHA}

Zajedničko za sve tradicionalne sisteme finansijske kontrole i merenja poslovnog uspeha je da se u celini zasnivaju na podacima koji se mogu dobiti na osnovu računovodstvenog sistema. Davanje pred- nosti korišćenju kvantitativnih računovodstvenih informacija obrazlaže se činjenicom da računovodstvo kao jedini integralni sistem kvantitavne analize preduzeća karakterišu integralnost obuhvata poslovnofinansijskih aktivnosti preduzeća, prednost numeričkog izraza i iz toga proizilazi vrednosni objektivizam. Takođe, prednost računovodstvenih informacija se manifestuje u njihovom svojstvu da različita stanja, tokove i relacije pretvori u jedan univerzalni, opšte prihvaćeni jedinstveni brojčani izraz.

Inače, integralni set finansijskih izveštaja većine preduzeća $\mathrm{u}$ međunarodnoj praksi čine bilans stanja ${ }^{2}$ (izveštaj o finansijskom položaju) i bilans uspeha (račun dobitka i gubitka). Mada je vremenom sve više favorizovan, izveštaj o tokovima gotovine nije prihvaćen u svim zemljama. ${ }^{3}$ I pored njihove baziranosti na istim poslovno-finansijskim transakcijama i univerzalnog finansijskog kvantifikovanja ovih transakcija, set finansijskih izveštaja kao objektivni hroničar preduzeća emituje različite informacije o njegovim aktivnostima za određeni period.

Osnovni informacioni sadržaj bilansa stanja (engl. Balance sheet) je knjigovodstvena vrednost preduzeća odnosno stanje aktive, obaveza i kapitala (neto vrednost aktive) na određeni dan.

Bilans uspeha (engl. Income statement) je poznat kao račun dobitka i gubitka (engl. P\&L - Profit and Loss Account). Osnovni informacioni sadržaj bilansa uspeha je profitabilnost. Bilans uspeha prikazuje

\footnotetext{
${ }^{2}$ Jedna od ključnih izmena u revidiranom IASI, objavljenom 2007. godine, odnosi se na zamenu naziva bilans stanja (Balance sheet) $u$ izveštaj o finansijskom položaju preduzeća (Statement of financial position). Kao razlog ove terminološke promene navodi se isticanje funkcije ovog osnovnog finansijskog izveštaja.

3 Prema prihvaćenim računovodstvenim standardima mala preduzeća u našoj zemlji su u obavezi da dostavljaju Agenciji za privredne registre (APR) osim bilansa stanja i bilansa uspeha $i$ statistički aneks, a srednja i velika preduzeća izveštaj o tokovima gotovine i izveštaj o promenama na kapitalu.
} 
informacije o prihodima, rashodima i neto dobitku/gubitku za određeni period. Međusobno konfrontirani svi prihodi i rashodi jednog konvencionalno usvojenog obračunskog perioda raščlanjeni i prikazani u skladu sa odgovarajućim principima i u odgovarajućoj izveštajnoj formi omogućavaju utvrđivanje rezultata dobitka kao pozitivne i gubitka kao negativne razlike, koja se na kraju obračunskog perioda obuhvataju u bilansu stanja kao povećanje i smanjenje (sopstvenog) kapitala. Ovakvo shvatanje bilansa uspeha ukazuje na postojanje sistematske i organske veze između bilansa stanja i bilansa uspeha, a ova činjenica ukazuje na to da se ovi finansijski izveštaji sa aspekta ocene efikasnosti poslovanja tretiraju kao komplementarni i međuzavisni proizvodi računovodstva [8].

Izveštaj o tokovima gotovina (engl. Statement of Cash Flows) pokazuje promet na računu gotovine preko priliva i odliva gotovine kao i generisan slobodan gotovinski tok u periodu. Izveštaj o tokovima gotovine pokazuje poslovne, finansijske i investicione prilive i odlive novčanih tokova preduzeća u toku izveštajnog perioda. Osnovna informacija za kontrolu koju izveštaj o tokovima gotovine nosi je likvidnost. Takođe, izveštaj o tokovima gotovine nosi informacije o mogućnostima stvaranja vrednosti ukoliko se izvrši diskontovanje slobodnog novčanog toka.

Pojedine pozicije finansijskih izveštaja, prikazane u apsolutnim vrednostima ne daju dovoljno informacija za upravljanje. Dovođenjem pojedinih pozicija bilansa stanja i bilansa uspeha $\mathrm{i}$ drugih izveštaja u odgovarajuće odnose dobijaju se racio brojevi. U procesu kontrole racio brojevi se porede sa prošlim rezultatima ili rezultatima konkurencije. Dakle, racio brojevi se mogu koristiti za praćenje rezultata preduzeća tokom vremena ili za praćenje relativne pozicije preduzeća u odnosu na konkurente. U svakom slučaju ove relativne vrednosti pružaju mnogo bogatije informacije $u$ odnosu na analizu apsolutnih veličina (pozicije finansijskih izveštaja). Sve racio brojeve možemo klasifikovati u četiri velike grupe: pokazatelje likvidnosti, pokazatelje obrta (aktivnosti), pokazatelje solventnosti (finansijske strukture) i pokazatelje rentabiliteta (profitabilnosti) [9].

Pomenuti pokazatelji predstavljaju, zapravo, operativna merila performansi, tj. pokazatelje uspeha koji mere rezultate operativnih odluka. Očigledno je da su u efektima operativnih odluka sadržani i efekti strategijskih i taktičkih odluka [10].

Pored jednostavnih racio brojeva postoje i složeni racio brojevi koji nastaju kombinovanjem osnovnih racio brojeva, praćenjem bitnog dela poslovnog procesa ili specifičnih aspekata poslovanja. Po osnovu DuPont formule dolazi se do sintetičkog izraza rentabilnosti koji omogućava da se ustanovi promena kao i uzroci promene rentabilnosti, jer se ukupna rentabilnost, tj. prinos na ukupna sredstva posmatra kao rezultat uzajamnog delovanja, ili interakcije parcijalnih pokazatelja rentabilnosti [11].

Značaj finansijskih izveštaja, koji odražavaju poslovno-finansijske aktivnosti preduzeća kao celine, ogleda se u tome što analitička interpretacija podataka sadržanih u njima omogućava identifikovanje i praćenje ključnih finansijskih merila efikasnosti preduzeća. Pored ovih tradicionalnih merila u poslednje vreme se koriste i pokazatelji koji imaju svoje uporište u konceptu upravljanja zasnovanog na vrednosti. Jedan od najznačajnijih je dodata ekonomska vrednost (Economic Value Added - EVA). Danas se često koriste od strane ekonomskih analitičara i pokazatelji profit pre kamate i poreza (Earning Before Interest and Taxes EBIT) i profit pre kamate, poreza, amortizacije i otpisa (Earning Before Interest, Taxes, Depreciation and Amortization EBITDA). 


\section{REZULTATI SAVREMENE \\ EKONOMSKE TEORIJE I PRAKSE U DEFINISANJU MODELA ZA MERENJE UKUPNOG POSLOVNOG USPEHA}

I pored nezamenljive uloge finansijskih merila potrebno je ukazati na njihovu nesavršenost i nepotpunost za potrebe validne analize i ocene efikasnosti. Primena tradicionalnih finansijskih merila pokazuje izvesne nedostatke i ograničenja koja se pre svega odnose na: prikazivanje događaja koji su se desili u prethodnom periodu, nepouzdanost baze poređenja za duži vremenski period, ne pridaju dovoljno važnosti poslovnom okruženju zanemarujući perspektivu potrošača konkurenata. Problem tradicionalnih merila koja se baziraju na finansijskim indikatorima je da ona ne uzimaju u obzir neopipljivu vrednost sadržanu u znanju koja u velikoj meri može da uveća tržišnu vrednost preduzeća.

Promene u okruženju, globalizacija svetske privrede, izražena konkurencija, razvoj informacione tehnologije dovodi do promena u tradicionalnoj upravljačkoj aparaturi. Industrijsku ekonomiju koju karakteriše fizički opipljiva aktiva zamenjuje nova ekonomija u kojoj najvredniji resurs postaje neopipljiva aktiva koja obuhvata odnose sa potrošačima, veštine zaposlenih i njihovo znanje, informacionu tehnologiju i organizacionu kulturu plodnu za inovacije, rešavanje problema i opšte unapređenje organizacije [12].

U uslovima razvijenog tržišta jedini održivi način za stvaranje vrednosti za vlasnike preduzeća je istovremeno ostvarivanje vrednosti i za njegove stejkholdere. Stejkholderi, dakle, imaju legitimne interese u obavljanju aktivnosti preduzeća, kao i određene zahteve i potrebe koje proizilaze iz povezanosti u obavljanju određene aktivnosti. Pri tome, primarni (aktivni) stejkholderi imaju formalne, zvanične i ugovorne odnose sa preduzećem, dok se svi ostali mogu tretirati sekundarnim (pasivnim). Orijentacija na stejkholdere podrazumeva da se u model poslovnog uspeha uključuju i pokazatelji uspešnosti u ostvarivanju pojedinačnih ciljeva svih stejkholdera kao i merenja ostvarivanja tih ciljeva, i jedno i drugo se izražavaju odgovarajućim indikatorima.

Jedna od najvažnijih uloga menadžmenta je da pronađe prihvatljiv balans između finansijske odgovornosti prema vlasnicima i strategijske odgovornosti prema ostalim stejkholderima. Menadžeri moraju poći od činjenice da je finansijska odgovornost preduslov za kasnije ispunjenje strategijske odgovornosti. Međutim, ovaj odnos nije jednosmeran. Viši kvalitet odnosa preduzeća sa stejkholderima kao što su potrošači, zaposleni, dobavljači, zajednica i dr. vodi boljim finansijskim performansama, a na kraju većoj vrednosti preduzeća i akcionarskog bogatstva [13].

$\mathrm{Na}$ prethodno navedenoj osnovi, a uvažavajući uzročno-posledične procese između samih stejkholdera formuliše se jedan od savremenih modela, tzv. Model Prizma performansi (A. Neely), koji se smatra integralnim modelom, zato što objedinjuje elemente modela orijentisanih na stejkholdere i elemente procesno orijentisanih modela [5]. Model prizma performansi je prikazan na slici 1 . 


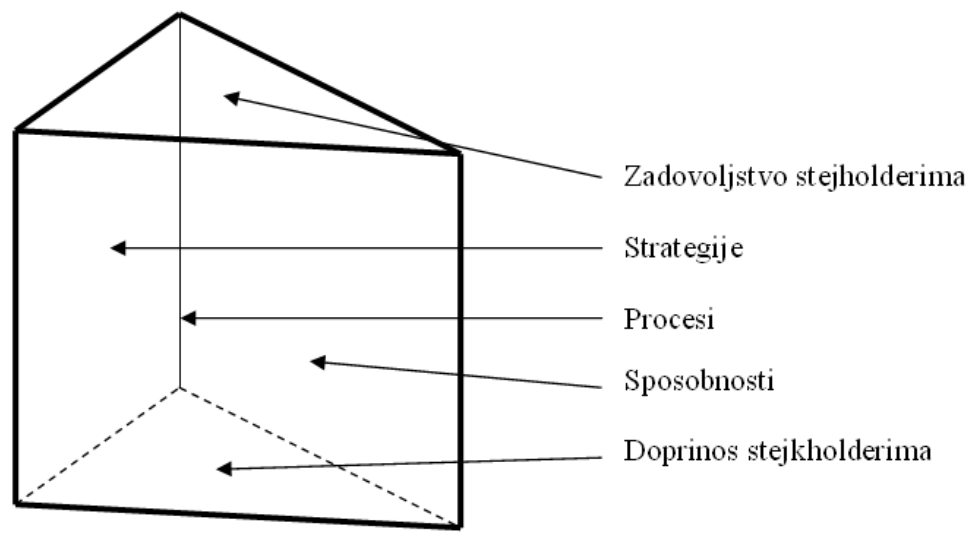

SI. 1. Prizma performansi kao model iskazivanja poslovnog uspeha (prema [14])

Model Prizma performansi pruža pet različitih, ali povezanih pogleda, a time i izraza poslovnog uspeha preduzeća iskaznog setom indikatora diferenciranih u pet ključnih grupa kao odgovora na pitanja [14]:

- zadovoljstvo stejkholderima (vrh prizme) - ko su ključni stejkholderi i šta oni žele, ili šta im treba;

- strategije poslovanja (strana prizme) - koju strategiju preduzeće treba da primeni da bi zadovoljilo navedene želje ili potrebe;

- procesi (strana prizme) - koje kritične procese preduzeće treba da primeni ka zadatom cilju, favorizujući tzv. procese koji dodaju vrednost na ulaganja i reprodukciju;

- sposobnost (strana prizme) - koje sposobnosti treba da imaju ključni stejkholderi (zaposleni, kupci, društvena zajednica i vlasnici kapitala) u ostvarivanju primenjenih procesa, i konačno

- doprinos stejkholdera (dno prizme) koje doprinose preduzeće može očekivati od stejkholdera, ako menadžment preduzeća podržava i razvija sposobnosti stejkholdera.

Upravljanje na bazi ovih merila podrazumeva definisanje ciljnih merila perfor- mansi, upoređivanje ostvarenja sa ciljnim vrednostima, identifikovanje odstupanja i uzroka (faktora) odstupanja, i na kraju identifikovanje korektivnih upravljačkih akcija. Model se smatra vrednim zato što ističe i dimenziju merila sposobnosti (resursa). Glavni nedostatak je preveliki broj merila, koja se s obzirom na ograničeno vreme i mogućnosti pažnje menadžera ne mogu operativno koristiti.

Brojna literatura dokazuje da primena višedimenzionalnih sistema merenja performansi doprinosi efektivnosti istih (Domanović, 2013. prema: Malina, M. A. \& Selto, F. H. 2001; Ittner, C.D. i dr. 2003; Davis, S. \& Albright, T. 2004; Crabtree, A. D. \& De Busk, G. K 2008; Van der Stede, W. A. i dr. 2006; Tung, A. i dr. 2011). Većina ovih studija ispitivala je efektivnost ovih sistema iz perspektiva doprinosa istih finansijskim rezultatima [15].

Analizirani modeli merenja poslovnog uspeha i drugi postojeći modeli koji su dakazali svoju primenljivost u praksi, od posebne su važnosti za unapređenje upravljačkog procesa. Kombinovanjem postojećih modela stvaraju se novi. Unapređeni sistemi merenja pružaju realne pretpostavke za efikasnije upravljanje uz odgovarajuću podršku informacionih sistema. 


\section{ZAKLJUČAK}

U ekonomskoj teoriji i poslovnoj praksi preduzeća vrlo je aktuelna i još uvek nedovoljno zaokružena problematika merenja ukupnog poslovnog uspeha. Sa upravljačkog aspekta dizajniranje kvalitetnog agregatnog merila zahteva prethodno rešavanje izuzetno kompleksnog problema svođenja na zajednički imenitelj različitih merila za inpute i outpute preduzeća kao i razvijanje i korišćenje odgovarjućeg informacionog sistema za proračun i praćenje tako projektovane agregatne veličine poslovnog uspeha. Ekonomska teorija u domaćoj literaturi je ponudila rešenje $u$ vidu originalnog modela Ekonometar. Modelom Ukupne performanse poslovne uspešnosti nastoje se prevazići određena ograničenja izvornog modela i njegovih kasnijih modifikacija posebno u pogledu korišćenja sistema finansijskog izveštavanja kao informacione osnove za proračun pojedinih elemenata.

Finansijska merila imaju nezamenljivu ulogu u oceni poslovnog uspeha preduzeća, međutim, neophodno je ukazati na njihovu nesavršenost i nepotpunost za potrebe validne analize poslovnog uspeha. U savremenom periodu dolazi do izražaja nemogućnost finansijskih pokazatelja da obuhvate nematerijalne resurse preduzeća (intelektualni kapital) i stepen ostvarenja nefinansijskih ciljeva preduzeća (odnos sa kupcima, zaposlenima) koji su u savremenom periodu kritični za poslovni uspeh preduzeća.

Efektivan sistem merenja je onaj koji uključuje set finasijskih i nefinasijskih merila koja će omogućiti menadžerima da se uspešno suoče sa velikim brojem poslovnih aktivnosti i fokusiraju na ključne faktore poslovnog uspeha. Model Prizma performansi je jedan od takvih predloga.

U cilju realnog sagledavanja efektivnosti i efikasnosti preduzeća i dalje će se tragati za rešenjima na koja će odgovor moći da pruži nova paradigma preduzeća i njoj primereni modeli.
Razmatrana problematika u radu je korisna za upravljanje rudarskim preduzećima koja će putem veće odgovornosti i prema svojim stejkholderima steći atribute uspešnog preduzeća.

\section{LITERATURA}

[1] M. Nikolić, N. Malenović, D. Pokrajčić, B. Paunović, Ekonomika preduzeća, Ekonomski fakultet, Beograd, 2005, str. 122, 136, 475.

[2] D. Grozdanović, Osnovi ekonomike preduzeća, Ekonomski fakultet, Kragujevac, 2003, str. 23, 25, 456.

[3] M. Milisavljević, Savremeni strategijski menadžment, Megatrend Univerzitet primenjenih nauka, Beograd, 2005, str. 5.

[4] Lj. Savić, Uloga menadžmenta u unapređenju efektivnosti i efikasnosti preduzeća, Doktorska disertacija, Megatrend univerzitet, Fakultet za poslovne studije, Beograd, 2010, str. 100.

[5] M. Ratković Abramović, Upravljanje dinamikom poslovnog uspeha, Autorsko izdanje, Beograd, 2005, str. 67,79.

[6] S. Kukoleča, Ekonometar, Konsalting centar, 1994, Beograd.

[7] B. Krstić, Model merenja performansi ukupne poslovne uspešnosti preduzeća, Ekonomski fakultet, Niš, 2007.

[8] V. Domanović, J. Bogićević, Mogućnosti primene Balanced Scorecard koncepta u Srbiji, Naučno društvo ekonomista Srbije, Naučni skup Novi metodi menadžmenta i marketinga $\mathrm{u}$ podizanju konkurentnosti srpske privrede, Palić, 2011.

[9] B. Pešalj, Merenje performansi preduzeća, Ekonomski fakultet, Beograd, 2006, str. 63 
[10] D. Đuričin, S. Janošević, Đ. Kaličanin, Menadžment i strategija, Ekonomski fakultet, Beograd, 2013, str. 161.

[11] D. Pokrajčić, Ekonomika preduzeća, Autorsko izdanje-Čigoja štampa, Beograd, 2002, str. 356.

[12] R. Kaplan and D. Norton, Having Trouble With Your Strategy? Then Mapit!, Harvard Business Review, September-October, 2000, p. 4.
[13] Đ. Kaličanin, Formulisanje i primena strategija stvaranja vrednosti, Doktorska disertacija, Ekonomski fakultet, Beograd, 2005, str. 15.

[14] A. Neely, Business Performance Measurement, Cambridge University Press, 2003, p. 153.

[15] V. Domanović, Efektivnost sistema merenja performansi u uslovima savremenog okruženja, Ekonomski horizonti, Ekonomski fakultet, Kragujevac, 2013. 